\title{
EFEKTIFITAS JENIS DESIKAN DAN KECEPATAN UDARA TERHADAP PENYERAPAN UAP AIR DI UDARA
}

\author{
EFFECTIVENESS OF VARIOUS DESICCANTS AND \\ AIR VELOCITY ON ADSORPTION OF WATER VAPOR FROM AIR
}

\author{
Rosdanelli Hasibuan, Ivo Dian Sari Marbun \\ Departemen Teknik Kimia, Fakultas Teknik, Universitas Sumatera Utara, \\ Jl. Almamater Kampus USU Medan 20155, Indonesia \\ Email: ivomarbun21@gmail.com
}

\begin{abstract}
Abstrak
Udara kering banyak digunakan dalam berbagai bidang, namun kandungan uap air yang berlebihan di udara akan menimbulkan beberapa masalah sehingga harus diminimalisir guna mendapatkan udara kering yang dibutuhkan. Penelitian ini bertujuan untuk mengkaji pengaruh jenis desikan dan kecepatan udara terhadap daya penyerapan uap air di udara yang dilakukan pada tray dryer. Proses penyerapan uap air dalam udara dilakukan dengan variasi kecepatan udara normal, 1,2 m/s, 2,3 m/s, dan 3,6 m/s atau laju volumetrik $0,059 \mathrm{~m}^{3} / \mathrm{s} ; 0,113 \mathrm{~m}^{3} / \mathrm{s} ; 0,178 \mathrm{~m}^{3} / \mathrm{s}$ dan jenis desikan silika gel, alumina, dan zeolit. Penyerapan uap air dalam udara oleh desikan dilakukan dengan cara menimbang massa desikan sebelum dan sesudah dilewati oleh udara setiap selang waktu 60 menit selama 3 jam. Pengukuran kelembaban udara dilakukan pada bagian hulu dan hilir tray dryer untuk mendapatkan penurunan kelembaban udara. Penyerapan uap air tertinggi mengunakan silika gel diperoleh pada kecepatan 2,3 $\mathrm{m} / \mathrm{s}$ dan 3,6 m/s dengan daya serap 0,266 gram uap air/gram adsorben dan 0,264 gram uap air/gram adsorben serta kelembaban udara akhir $0,0194 \mathrm{~kg}$ uap air $/ \mathrm{kg}$ udara kering dan $0,0198 \mathrm{~kg}$ uap air $/ \mathrm{kg}$ udara kering. Penyerapan uap air tertinggi mengunakan alumina diperoleh pada kecepatan $2,3 \mathrm{~m} / \mathrm{s}$ dan $3,6 \mathrm{~m} / \mathrm{s}$ dengan daya serap 0,147 gram uap air/gram adsorben dan 140 gram uap air/gram adsorben serta kelembaban udara akhir $0,0207 \mathrm{~kg}$ uap air/kg udara kering dan 0,0194 kg uap air/kg udara kering dan penyerapan uap air tertinggi mengunakan zeolit diperoleh pada kecepatan $3,6 \mathrm{~m} / \mathrm{s}$ dengan daya serap 0,130 gram uap air/gram adsorben serta kelembaban udara akhir 0,0193 kg uap air/kg udara kering. Silika gel merupakan desikan terbaik dalam proses penyerapan uap air di udara dibandingkan alumina dan zeolit.
\end{abstract}

Kata kunci: Kelembapan udara, silika gel, alumina, zeolit, udara

\begin{abstract}
Dry air is widely used in many fields, but the excessive water vapor in the air will make some problem and should be minimized to get the required dry air. The purpose of this research to observe the effect of air velocity and various of desiccants on the absorption of water vapor in the air on the tray dryer. The process of absorption of water vapor in the air performed with variations of the normal air velocity, $1.2 \mathrm{~m} / \mathrm{s}, 2.3 \mathrm{~m} / \mathrm{s}$, and $3.6 \mathrm{~m} / \mathrm{s}$ or volumetric rate of $0.059 \mathrm{~m}^{3} / \mathrm{s} ; 0.113 \mathrm{~m}^{3} / \mathrm{s} ; 0.178 \mathrm{~m}^{3} / \mathrm{s}$ and the type of desiccant of silica gel, alumina, and zeolite. Adsorption of water vapor in the air by desiccant was done by weighing the mass of desiccant before and after being crossed by air every interval of 60 minutes for 3 hours. Humidity measurement are performed on the upstream and downstream of the tray dryer to obtain a decrease in air humidity. The highest moisture adsorption using silica gel was obtained at velocities of $2.3 \mathrm{~m} / \mathrm{s}$ and $3.6 \mathrm{~m} / \mathrm{s}$ with adsorption of 0.266 grams water vapor / grams adsorbent and 0.264 grams water vapor / grams adsorbent as well as humidity of final air of $0.0194 \mathrm{~kg}$ water vapor/ $\mathrm{kg}$ dry air and $0.0198 \mathrm{~kg}$ water vapor/ $\mathrm{kg}$ dry air . The highest adsorption of water vapor using alumina was obtained at velocities of $2.3 \mathrm{~m} / \mathrm{s}$ and $3.6 \mathrm{~m} / \mathrm{s}$ with adsorption of 0.147 grams water vapor / gram adsorbent and 0.140 grams water vapor / gram adsorbent and the final humidity of $0.0207 \mathrm{~kg}$ water vapor / $\mathrm{kg}$ dry air and $0.0194 \mathrm{~kg}$ water vapor / $\mathrm{kg}$ dry air and the highest water vapor adsorption using zeolite was obtained at $3.6 \mathrm{~m} / \mathrm{s}$ with the adsorption capacity of 0.130 grams water vapor / grams adsorbent and the final humidity of $0.0193 \mathrm{~kg}$ water vapor $/ \mathrm{kg}$ dry air. Silica gel was the best desiccant in the process of moisture adsorption in air compared to alumina and zeolite.
\end{abstract}

Keywords: Humidity, silica gel, alumina, zeolite, air 


\section{Pendahuluan}

Udara kering merupakan salah satu kebutuhan yang penting dalam bidang, baik di industri, kesehatan maupun kondisi lingkungan. Udara kering berarti udara yang mengandung sedikit uap air. Setiap udara kering memiliki susunan yang sama, namun jumlah uap airnya berbeda tergantung tempat dan keadaan udara di sekitarnya. Keberadaan uap air di udara selain mengancam kesehatan juga merusak perabotan rumah tangga dan alat elektronik yang mengalami korosi, serta menyebabkan munculnya beberapa jenis jamur [7].

Untuk itu keberadaan uap air dalam udara ini harus diminimalisir untuk mengurangi kandungan uap air dalam udara. Salah satu alternatif pengembangan proses pengurangan uap air ini adalah dengan metode adsorpsi. Jenis desikan pada adsorpsi disesuaikan dengan sifat dan keadaan zat yang diadsorpsi karena beberapa jenis adsorben yang memiliki sifat yang spesifik hanya menyerap zat tertentu [6].

Pada proses ini, uap air dalam udara dijerap oleh desikan, sehingga udara menjadi lebih kering. Pada saat yang bersamaan, suhu udara akan naik karena adanya panas adsorpsi yang dilepaskan. Proses pengeringan adsorpsi ini terbukti dapat mengurangi konsumsi energi sekitar 16-20\% [11]. Diharapkan penelitian ini dapat meningkatkan efektifitas penyerapan dengan metode adsorpsi serta memenuhi kualitas produk yang di inginkan untuk dapat dikembangkan pada skala industri.

\section{Teori}

Adsorpsi adalah suatu proses dimana suatu komponen yang terdapat pada suatu zat dihilangkan atau diserap dengan menggunakan padatan. Prinsip adsorpsi dapat diterapkan untuk kebanyakan proses pemisahan padat-cair [14].

Adsorpsi meliputi penyerapan permukaan antara dua fasa, dimana terdapat gaya kohesif elektrostatis dan ikatan hidrogen. Gaya permukaan yang tidak stabil dikarenakan adanya perubahan konsentrasi molekul pada permukaan padatan/cairan. Proses adsorpsi merupakan pemisahan substansi dari satu zat berkonsentrasi tinggi pada permukaan bahan lain. Bahan pengabsorp disebut adsorben, dan material yang diserap disebut adsorbat [4].

Proses adsorpsi dapat berlangsung jika padatan atau molekul gas atau cair dikontakkan dengan molekul-molekul adsorbat maka didalamnya terdapat gaya kohesif atau gaya hidrostatik dan gaya ikatan hidrogen yang bekerja diantara molekul seluruh material. Gaya-gaya yang tidak seimbang menyebabkan perubahanperubahan konsentrasi molekul pada interface solid/fluida. Molekul fluida yang diserap tetapi tidak terakumulasi/melekat ke permukaan adsorben disebut adsorptif sedangkan yang terakumulasi/ melekat disebut adsorbat [1].

Desiccant berarti bahan penyerap. Desikan adalah zat atau bahan yang memproduksi udara kering dikarenakan bahan desikan menyerap kelembaban dari udara lingkungan. Udara yang telah mengalami dehumidifikasi tidak hanya kering, namun suhu lingkungan juga meningkat sesuai dengan isothermal proses. Desikan yang terdapat didalam alat pengering dari instalasi refrigerasi dipergunakan terutama untuk menyerap dan menghilangkan uap air yang ada didalam udara.

Desikan berbentuk padatan disebut adsorben. Kebanyakan adsorben adalah bahanbahan yang sangat berpori dan adsorpsi berlangsung terutama pada dinding-dinding pori atau pada letak - letak tertentu didalam partikel. Biasanya luasnya berada dalam orde $200-1000$ $\mathrm{m}^{2} / \mathrm{g}$ adsorben. Diameter pori sebesar 0,0003 $0,02 \mu \mathrm{m}$. Beberapa jenis adsorben komersial memiliki standar luas permukaan yaitu alumina aktif $200-500 \mathrm{~m}^{2} / \mathrm{g}$; silika gel $400-800 \mathrm{~m}^{2} / \mathrm{g}$; karbon aktif 300-1.200 m²/g; karbon molecular sieve $400 \mathrm{~m}^{2} / \mathrm{g}$; dan zeolit 200-600 m²/g [8].

Beberapa adsorben yang sering digunakan adalah zeolit, clay, silika, karbon aktif, dan lainnya. Parameter yang cukup penting dari adsorben adalah luas permukaan yang dimiliki. Peningkatan luas permukaan adsorben akan meningkatkan kapasitas adsorben sehingga jumlah adsorbat yang dapat diserap semakin besar [16]. Adsorbat adalah substansi dalam bentuk cair atau gas yang terkonsentrasi pada permukaan adsorben. Adsorbat yang biasa digunakan pada sistem pendingin adalah air (polar substances) dan kelompok non polar substances seperti methanol, etanol dan kelompok hirokarbon [3].

\section{Metodologi Penelitian \\ Bahan dan Peralatan}

Bahan yang digunakan dalam penelitian ini adalah silika gel, alumina dan zeolit sebagai desikan Adapun peralatan yang digunakan dalam penelitian ini adalah alat pengering kabinet atau alat pengering tipe rak atau lebih popular dengan tray dryer sebagai alat utama yang terdiri dari 3 bagian yaitu:

1. Bagian hulu dengan panjang $42 \mathrm{~cm}$ lebar, $28 \mathrm{~cm}$ dan tinggi $28 \mathrm{~cm}$. Pada bagian ini terdapat tombol on/off dan switch control air flow dan suhu, juga terdapat tombol meter supply dan kabel penyambung ke stop kontak.

2. Bagian tengah dengan panjang $98 \mathrm{~cm}$, lebar 28 $\mathrm{cm}$ dan tinggi $28 \mathrm{~cm}$. Pada bagian ini terdapat 
ruang pengering yang berdimensi $50 \mathrm{~cm} \times 50$ $\mathrm{cm} \times 50 \mathrm{~cm}$ dengan 3 buah rak tempat bahan yang akan dikeringkan. Di bagian hulu dan hilirnya terdapat celah yaitu tempat termometer dipasang.

3. Bagian hilir dengan panjang $47 \mathrm{~cm}$, lebar 22,5 $\mathrm{cm}$ dan tinggi $22 \mathrm{~cm}$. Merupakan ruang keluarnya udara lembab dengan luas yang lebih kecil pada bagian ujungnya.

\section{Prosedur Kerja}

Adapun prosedur yang akan dilakukan pada penelitian ini adalah Alat pengering baki dipersiapkan kemudian Termometer dan $\mathrm{RH}-$ meter dipasang, lalu dicatat suhu dan kelembaban udaranya. Kecepatan udara di atur kemudian Desikan ditimbang sebanyak 150 gram dan dimasukkan ke dalam ruang pengering baki dan setiap 1 jam suhu dan kelembaban udara di catat lalu desikan dikeluarkan dari pengering baki untuk ditimbang menggunakan neraca elektrik. Penelitian dilakukan sampai jam ke-3.

Percobaan yang sama dilakukan hingga 2 kali (duplo) kemudian data yang didapatkan dicatat. Percobaan dilanjutkan dengan variasi desikan silika gel, alumina dan zeolit, serta variasi kecepatan volumetrik udara normal $0,059 \mathrm{~m}^{3} / \mathrm{s}$; $0,113 \mathrm{~m}^{3} / \mathrm{s} ; 0,178 \mathrm{~m}^{3} / \mathrm{s}$. Data yang diperoleh dicatat lalu akan digunakan dalam perhitungan untuk memperoleh efisiensi desikan

\section{Hasil}

Penelitian ini mengkaji proses penyerapan uap air yang ada di udara. Proses penyerapan uap air di udara dilakukan dengan cara melewatkan udara melalui desikan dengan kecepatan volumetrik udara normal $0,059 \mathrm{~m}^{3} / \mathrm{s} ; 0,113 \mathrm{~m}^{3} / \mathrm{s}$; $0,178 \mathrm{~m}^{3} / \mathrm{s}$ dan desikan silika gel, alumina dan zeolit.

\section{Daya Serap Variasi Jenis Desikan Terhadap Uap Air di Uara}

\section{Daya Serap Silika Gel terhadap Uap Air di Udara Pada Berbagai Kecepatan}

Kecepatan udara merupakan salah satu faktor yang berpengaruh dalam proses penyerapan uap air di udara. Daya serap desikan terhadap uap air di udara pada kecepatan volumetrik udara normal $0,059 \mathrm{~m}^{3} / \mathrm{s} ; 0,113 \mathrm{~m}^{3} / \mathrm{s}$; $0,178 \mathrm{~m}^{3} / \mathrm{s}$ menggunakan desikan silika gel disajikan pada Gambar 1.

Gambar 1 menunjukkan profil daya serap silika gel terhadap uap air di udara pada variasi kecepatan. Keempat kecepatan udara memberikan trend yang sama, dimana daya penyerapan desikan semakin meningkat seiring bertambahnya waktu.

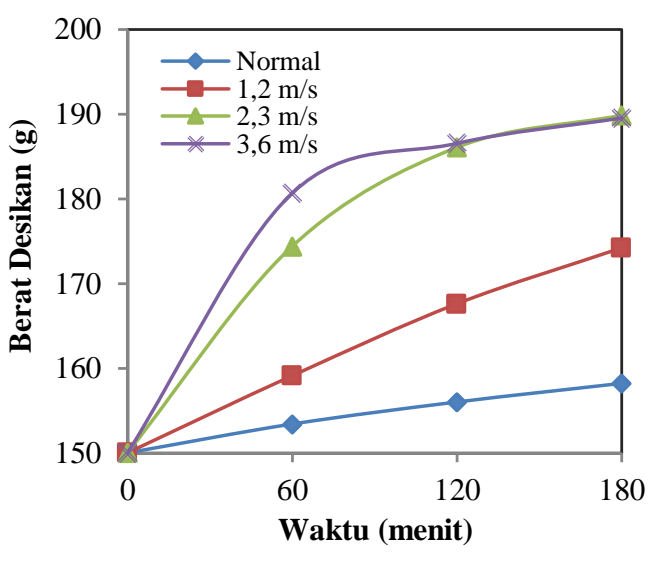

Gambar 1. Pengaruh Kecepatan Udara terhadap Daya Serap Silika Gel terhadap Uap Air di Udara

Peningkatan ini terjadi karena desikan belum mencapai titik jenuh sehingga masih menyerap hingga pada menit ke-180. Namun pada kecepata $0,178 \mathrm{~m}^{3} / \mathrm{s}$ di menit ke-120 daya penyerapan silika menjadi berkurang sehingga berada pada kondisi yang hampir sama dengan kecepatan $0,113 \mathrm{~m}^{3} / \mathrm{s}$. Hal ini dikarenakan desikan pada kecepatan $0,178 \mathrm{~m}^{3} / \mathrm{s}$ menyerap uap air lebih banyak yang menyebabkan desikan lebih cepat jenuh dan menurun dimenit ke-120. Ini mengindikasikan bahwa desikan menggunakan kecepatan udara yang lebih tinggi memiliki daya penyerapan yang lebih cepat. Penyerapan mengunakan silika gel pada kecepatan $0,178 \mathrm{~m}^{3} / \mathrm{s}$ $\mathrm{s}$ dicapai pada menit ke-120. Pada kecepatan volumetrik $0,059 \mathrm{~m}^{3} / \mathrm{s} ; 0,113 \mathrm{~m}^{3} / \mathrm{s} ; 0,178 \mathrm{~m}^{3} / \mathrm{s}$ berat desikan yang awalnya 150 gram masingmasing menjadi 158,2; 174,2; 189,9; dan 189,6 gram dengan jumlah uap air yang diserap sebesar 8,2; 24,2; 39,9; dan 39,6 gram. Daya serap silika gel terhadap uap air tertinggi diperoleh pada kecepatan udara $0,113 \mathrm{~m}^{3} / \mathrm{s}$ dan $0,178 \mathrm{~m}^{3} / \mathrm{s}$ dengan daya serap 0,266 dan 0,264 gram uap air/gram adsorben. Semakin besar kecepatan udara maka daya serap desikan terhadap udara semakin besar pula, sesuai dengan percobaan yang dilakukan oleh Chu, dkk [5] laju alir udara yang lebih tinggi, akan menyebabkan proses mencapai kondisi jenuh menjadi lebih cepat karena jumlah uap air yang diserap lebih banyak. Hal ini juga sesuai dengan teori penurunan nilai moisture content dimana pada kecepatan udara tinggi proses penurunan moisture content menjadi lebih cepat dikarenakan uap air di udara lebih cepat diserap [9].

Profil Humidity (H) pada kecepatan kecepatan volumetrik $0,059 \mathrm{~m}^{3} / \mathrm{s} ; 0,113 \mathrm{~m}^{3} / \mathrm{s}$; $0,178 \mathrm{~m}^{3} / \mathrm{s}$ menggunakan desikan silika gel disajikan pada Gambar 2. 


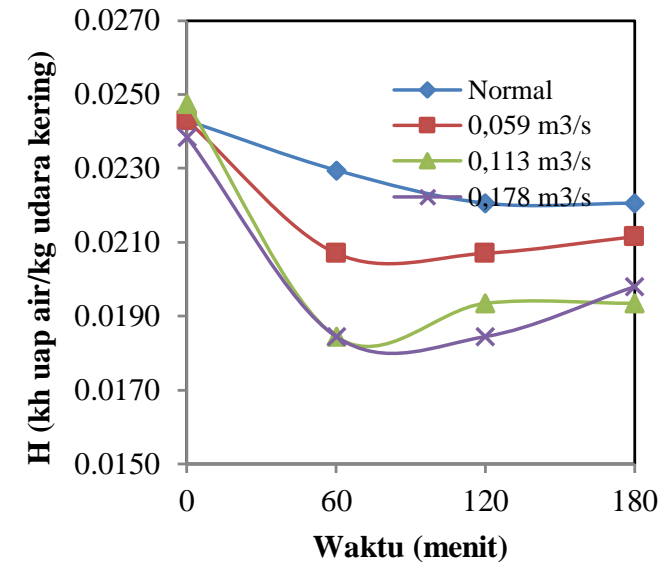

Gambar 2. Pengaruh Kecepatan Udara terhadap Profil Humidity (H) Menggunakan Silika Gel

Gambar 2 menunjukkan bahwa profil humidity $(\mathrm{H})$ pada kondisi akhir udara untuk setiap kecepatan udara memiliki tren yang sama dengan profil relative humidity $(\mathrm{RH})$. Hal ini menunjukkan adanya hubungan berbanding lurus antara relative humidity $(\mathrm{RH})$ dan humidity $(\mathrm{H})$. Hasil ini sesuai dengan percobaan yang dilakukan oleh Siti, dkk [15] dan Mitsuhiro, dkk [12]. Penurunan kelembaban udara mengindikasikan bahwa terjadi penyerapan uap air dari udara oleh desikan. Nilai penurunan relative humidity $(\mathrm{RH})$ pada kecepatan kecepatan volumetrik $0,059 \mathrm{~m}^{3} / \mathrm{s}$ ; $0,113 \mathrm{~m}^{3} / \mathrm{s} ; 0,178 \mathrm{~m}^{3} / \mathrm{s}$ masing-masing dari $\mathrm{RH}$ awal $84 \%, 84 \%, 85 \%$ dan $83 \%$ menjadi $79 \%$, $77 \%, 73 \%$, dan $74 \%$, dengan kelembaban udara akhir sebesar 0,0221;0,0212;0,0194 dan 0,0198 $\mathrm{kg}$ uap air/ kg udara kering. Dimana penurunan RH yang paling tinggi diperoleh pada kecepatan udara $0,113 \mathrm{~m}^{3} / \mathrm{s} \mathrm{m} / \mathrm{s}$ dengan penurunan $\mathrm{RH}$ sebesar $12 \%$.

\section{Daya Serap Alumina terhadap Uap Air di Udara Pada Berbagai Kecepatan}

Daya serap alumina terhadap uap air di udara pada kecepatan kecepatan volumetrik 0,059 $\mathrm{m}^{3} / \mathrm{s} ; 0,113 \mathrm{~m}^{3} / \mathrm{s} ; 0,178 \mathrm{~m}^{3} / \mathrm{s}$ menggunakan desikan alumina disajikan pada Gambar 3 . Gambar 3 menunjukkan profil daya serap alumina terhadap uap air di udara pada variasi kecepatan. Keempat kecepatan udara memberikan tren yang sama dimana penyerapan uap air meningkat secara perlahan hingga pada akhir penyerapan desikan belum mencapai titik jenuh. Hal ini menunjukkan bahwa daya serap desikan pada waktu yang ditentukan cukup kecil sehingga dibutuhkan waktu penyerapan yang lebih lama untuk menentukan titik jenuh alumina. Pada kecepatan volumetrik udara normal $0,059 \mathrm{~m}^{3} / \mathrm{s}$; $0,113 \mathrm{~m}^{3} / \mathrm{s} ; 0,178 \mathrm{~m}^{3} / \mathrm{s}$. Berat desikan yang awalnya 150 gram masing-masing menjadi 158,8 ;
162,$0 ; 172,1$; dan 171,0 gram dengan jumlah uap air yang diserap sebesar 8,$8 ; 12,0 ; 22,1$; dan 21,0 gram. Secara umum, pernyataan laju alir udara yang lebih tinggi, akan menyebabkan proses mencapai kondisi jenuh menjadi lebih cepat karena jumlah uap air yang diserap lebih banyak. Hal ini juga sesuai dengan teori penurunan nilai moisture content dimana pada kecepatan udara tinggi proses penurunan moisture content menjadi lebih cepat dikarenakan uap air di udara lebih cepat diserap [9].

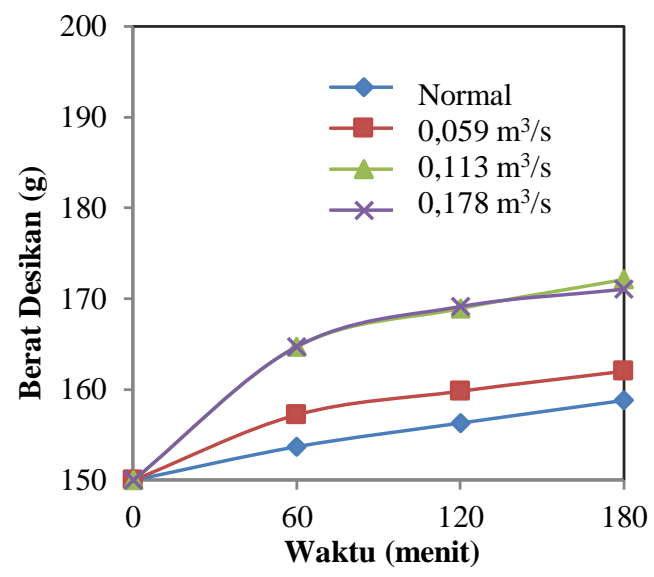

Gambar 3. Pengaruh Kecepatan Udara terhadap Daya Serap Alumina terhadap Uap Air di Udara

Namun pada grafik ini, kecepatan udara $0,113 \mathrm{~m}^{3} / \mathrm{s}$ memiliki daya penyerapan yang lebih tinggi dibandingkan dengan kecepatan udara $0,178 \mathrm{~m}^{3} / \mathrm{s}$ meski perbedaan yang dihasilkan tidak begitu jauh. Hal ini dikarenakan kecepatan udara yang lebih besar menyebabkan waktu kontak desikan dengan udara semakin cepat, sehingga daya penyerapan desikan menjadi lebih kecil [5]. Daya serap alumina terhadap uap air tertinggi diperoleh pada kecepatan udara $0,113 \mathrm{~m}^{3} / \mathrm{s}$ dan $0,178 \mathrm{~m}^{3} / \mathrm{s}$ dengan daya serap 0,147 dan 0,140 gram uap air/gram adsorben.

Daya serap alumina terhadap uap air Profil Humidity $(\mathrm{H})$ pada kecepatan volumetrik udara normal $0,059 \mathrm{~m}^{3} / \mathrm{s} ; 0,113 \mathrm{~m}^{3} / \mathrm{s} ; 0,178 \mathrm{~m}^{3} / \mathrm{s}$ menggunakan desikan alumina disajikan pada Gambar 4. Gambar 4 menunjukkan bahwa profil humidity $(\mathrm{H})$ pada kondisi akhir udara untuk setiap kecepatan udara memiliki tren yang sama dengan profil relative humidity $(\mathrm{RH})$. Hal ini menunjukkan adanya hubungan berbanding lurus antara relative humidity $(\mathrm{RH})$ dan humidity $(\mathrm{H})$. Hasil ini sesuai dengan percobaan yang dilakukan oleh Siti, dkk [15] dan Mitsuhiro, dkk [12]. Penurunan relative humidity mengindikasikan bahwa terjadi penyerapan uap air dari udara oleh desikan. 


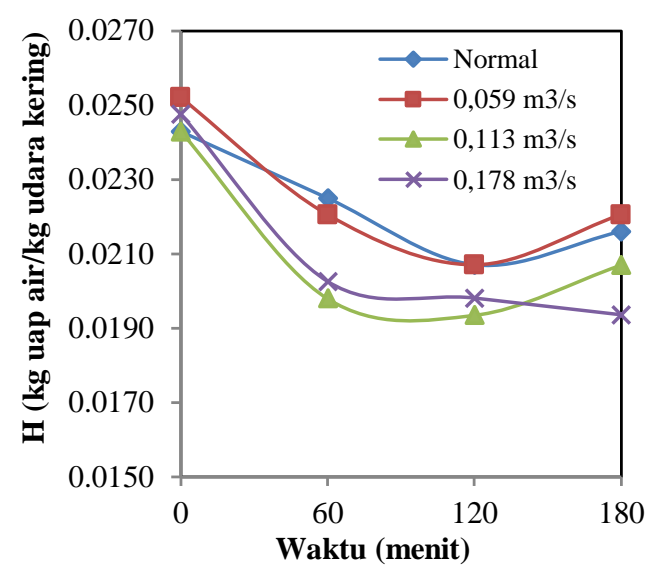

Gambar 4. Pengaruh Kecepatan Udara terhadap Profil Humidity (RH) Menggunakan Alumina

Nilai penurunan relative humidity ( $\mathrm{RH})$ pada volumetrik udara normal $0,059 \mathrm{~m}^{3} / \mathrm{s} ; 0,113$ $\mathrm{m}^{3} / \mathrm{s} ; 0,178 \mathrm{~m}^{3} / \mathrm{s}$ dari RH awal $84 \%, 86 \%, 85 \%$ dan $85 \%$ masing-masing menjadi $78 \%, 79 \%$, $76 \%$, dan $73 \%$, dengan kelembaban udara akhir sebesar 0,$0216 ; 0,0221 ; 0,0207$ dan $0,0194 \mathrm{~kg}$ uap air/ kg udara kering. Dimana penurunan RH yang paling tinggi diperoleh pada kecepatan udara $0,178 \mathrm{~m}^{3} / \mathrm{s}$ dengan persen penurunan $\mathrm{RH}$ sebesar $12 \%$.

\section{Daya Serap Zeolit terhadap Uap Air di Udara Pada Berbagai Kecepatan}

Daya serap zeolit terhadap uap air di udara pada volumetrik udara normal $0,059 \mathrm{~m}^{3} / \mathrm{s} ; 0,113$ $\mathrm{m}^{3} / \mathrm{s} ; 0,178 \mathrm{~m}^{3} / \mathrm{s}$ menggunakan desikan zeolit disajikan pada Gambar 5.

Gambar 5 menunjukkan profil daya serap zeolit terhadap uap air di udara pada variasi kecepatan udara. Keempat kecepatan udara memberikan tren yang sama dimana penyerapan uap air meningkat secara perlahan hingga pada akhir penyerapan desikan belum mencapai titik jenuh. Hal ini menunjukkan bahwa daya serap zeolit pada waktu yang ditentukan cukup kecil sehingga dibutuhkan waktu penyerapan yang lebih lama untuk menentukan titik jenuh zeolit. Pada kecepatan volumetrik udara normal, 0,059 $\mathrm{m}^{3} / \mathrm{s} ; 0,113 \mathrm{~m}^{3} / \mathrm{s} ; 0,178 \mathrm{~m}^{3} / \mathrm{s}$. Berat desikan yang awalnya 150 gram masing-masing menjadi 156,4 ; 158,$2 ; 159,3$ dan 170,1 gram dengan jumlah uap air yang diserap sebesar 6,$4 ; 8,2 ; 9,3$; dan 20,1 gram. Daya serap zeolit terhadap uap air tertinggi diperoleh pada kecepatan udara $0,178 \mathrm{~m}^{3} / \mathrm{s}$ dengan daya serap 0,134 gram uap air/gram adsorben.

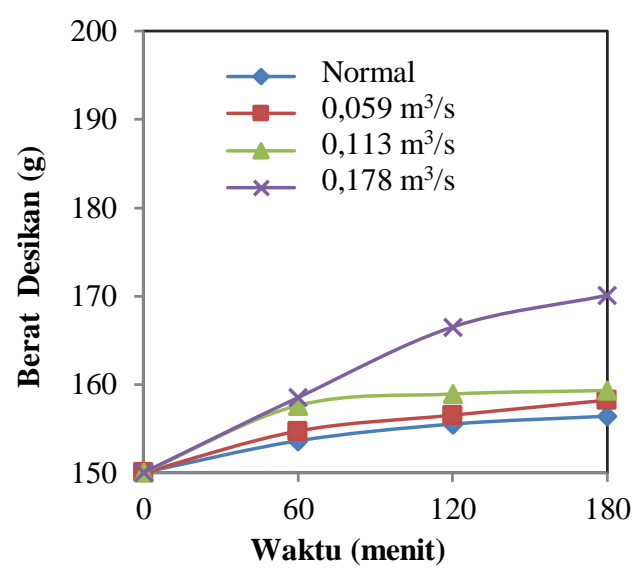

Gambar 5. Pengaruh Kecepatan Udara terhadap Daya Serap Zeolit terhadap Uap Air

Semakin besar kecepatan udara maka efisiensi penyerapan udara semakin besar pula, ini sesuai dengan percobaan yang dilakukan oleh Chu, dkk [5] dan laju alir udara yang lebih tinggi, akan menyebabkan proses mencapai kondisi jenuh menjadi lebih cepat karena jumlah uap air yang diserap lebih banyak. Hal ini juga sesuai dengan teori penurunan nilai moisture content dimana pada kecepatan udara tinggi proses penurunan moisture content menjadi lebih cepat dikarenakan uap air di udara lebih cepat diserap [9].

Profil Humidity (H) pada kecepatan volumetrik udara normal, $0,059 \mathrm{~m}^{3} / \mathrm{s} ; 0,113 \mathrm{~m}^{3} / \mathrm{s}$ ; $0,178 \mathrm{~m}^{3} / \mathrm{s}$ menggunakan desikan zeolit disajikan pada Gambar 6

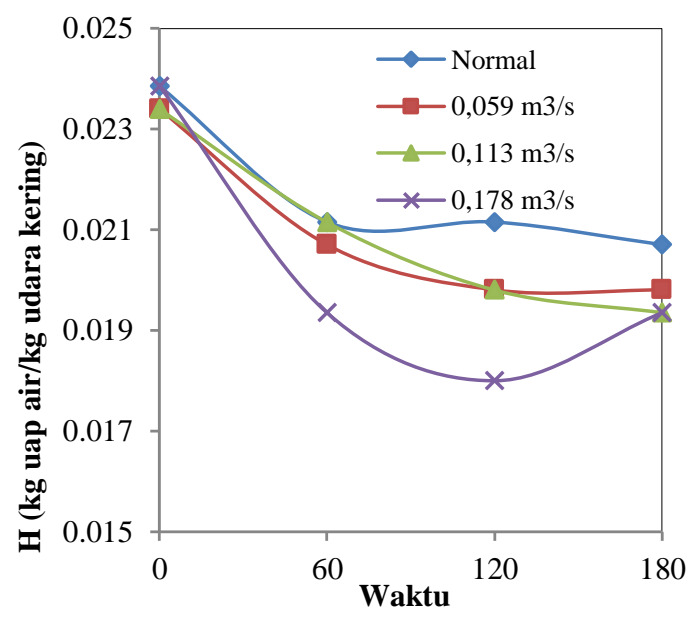

Gambar 6. Pengaruh Kecepatan Udara terhadap Profil Humidity (RH) Menggunakan Zeolit

Gambar 6 menunjukkan bahwa profil humidity $(\mathrm{H})$ pada kondisi akhir udara untuk setiap kecepatan udara memiliki tren yang sama 
dengan profil relative humidity $(\mathrm{RH})$. Hal ini menunjukkan adanya hubungan berbanding lurus antara relative humidity $(\mathrm{RH})$ dan humidity $(\mathrm{H})$.

Hasil ini sesuai dengan percobaan yang dilakukan oleh Siti,dkk [15] dan Mitsuhiro, dkk [12]. Penurunan relative humidity mengindikasikan bahwa terjadi penyerapan uap air dari udara oleh desikan. Nilai penurunan relative humidity $(\mathrm{RH})$ pada kecepatan volumetrik udara normal, $0,059 \mathrm{~m}^{3} / \mathrm{s} ; 0,113 \mathrm{~m}^{3} / \mathrm{s} ; 0,178 \mathrm{~m}^{3} / \mathrm{s}$ dari RH awal $83 \%, 82 \%, 82 \%$ dan $83 \%$ menjadi $76 \%, 74 \%, 73 \%$ dan $73 \%$ dengan kelembaban udara akhir sebesar 0,0207;0,0198;0,0194 dan $0,0193 \mathrm{~kg}$ uap air/ $\mathrm{kg}$ udara kering. Dimana penurunan $\mathrm{RH}$ yang paling tinggi diperoleh pada kecepatan udara $0,178 \mathrm{~m}^{3} / \mathrm{s}$ dengan persen penurunan RH sebesar $10 \%$.

Dari ketiga grafik daya serap desikan terhadap uap air pada variasi kecepatan udara dapat disimpulkan bahwa kecepatan udara yang terbaik adalah $0,113 \mathrm{~m}^{3} / \mathrm{s}$ dan $0,178 \mathrm{~m}^{3} / \mathrm{s}$ untuk silika dan alumina serta $0,178 \mathrm{~m}^{3} / \mathrm{s}$ untuk zeolit yang dijelaskan pada Gambar 7.

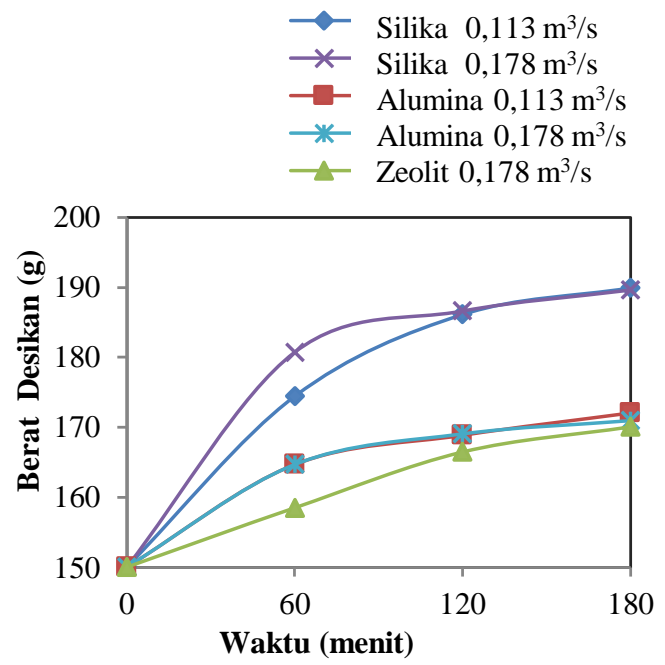

Gambar 7. Pengaruh Jenis Desikan terhadap Daya Serap Desikan terhadap Uap Air pada Kecepatan Terbaik

Gambar 7 menunjukkan profil daya serap desikan terhadap uap air di udara untuk ketiga jenis desikan. Penyerapan uap air oleh silika gel pada kecepatan $0,113 \mathrm{~m}^{3} / \mathrm{s}$ dan $0,178 \mathrm{~m}^{3} / \mathrm{s}$ memiliki berat awal yaitu 150 gram menjadi 189,9 dan 189,6 gram dan jumlah uap air yang diserap sebesar 39,9 dan 39,6 gram, penyerapan uap air oleh alumina pada kecepatan $0,113 \mathrm{~m}^{3} / \mathrm{s}$ dan $0,178 \mathrm{~m}^{3} / \mathrm{s}$ memiliki berat awal yaitu 150 gram menjadi 172,1 dan 171,0 gram dan jumlah uap air yang diserap sebesar 22,2 dan 21,0 gram, dan penyerapan uap air oleh zeolit pada kecepatan $0,178 \mathrm{~m}^{3} / \mathrm{s} \mathrm{m} / \mathrm{s}$ memiliki berat awal yaitu 150 gram menjadi 170,1 gram dan jumlah uap air yang diserap sebesar 20,1 gram. Dari hasil ini diperoleh daya serap silika gel sebesar 0,266 dan 0,264 gram uap air/gram adsorben, alumina sebesar 0,147 dan 0,140 gram uap air/gram adsorben, dan zeolit sebesar 0,134 gram uap air/gram adsorben. Dari penjelasan diatas, desikan yang memiliki daya penyerapan uap air terbaik adalah silika gel.

Hal ini disebabkan karena silika memiliki luas permukaan dan diameter pori yang lebih luas yaitu sekitar $400-800 \mathrm{~m}^{2} / \mathrm{g}$ dan $20 \AA$ sedangkan alumina sekitar $200-500 \mathrm{~m}^{2} / \mathrm{g}$ dan $10 \AA$ dan zeolit sekitar $50-200 \mathrm{~m}^{2} / \mathrm{g}$ dan $15 \AA$ dimana salah satu faktor penting dalam proses adsorpsi adalah luas permukaan desikan. Semakin luas permukaan desikan maka proses penyerapan akan semakin besar karena uap air yang akan diserap juga semakin besar. Namun ukuran diameter pori yang besar menyebabkan luas bidang permukaan kecil sehingga pori-pori makin sedikit dan kemampuan adsorpsi terhadap adsorben ini berkurang. Hal ini yang menyebabkan kemampuan adsorbat untuk menempel pada pori-pori adsorben makin berkurang [10].

Profil penurunan kelembaban udara $(\mathrm{RH})$ pada penggunaan jenis desikan silika gel, alumina dan zeolit disajikan pada Gambar 8.



Gambar 8. Pengaruh Jenis Desikan terhadap Profil Humidity (H) Pada Kecepatan Terbaik

Gambar 8 menunjukkan bahwa kelembaban udara (RH) untuk ketiga jenis desikan cenderung mengalami penurunan seiring bertambahnya waktu. Hasil ini sesuai dengan percobaan yang dilakukan oleh Siti, dkk [15] dan Mitsuhiro, dkk [12]. Penurunan kelembaban udara mengindikasikan bahwa terjadi penyerapan uap air dari udara oleh desikan. Dengan menggunakan silika gel pada kecepatan 0,113 $\mathrm{m}^{3} / \mathrm{s}$ nilai relative humidity $(\mathrm{RH})$ yang awalnya $85 \%$ menjadi $73 \%$ sehingga diperoleh persen 
penurunan RH sebesar 12\%, dengan menggunakan alumina kecepatan $0,178 \mathrm{~m}^{3} / \mathrm{s}$ nilai relative humidity (RH) yang awalnya $85 \%$ menjadi $73 \%$ sehingga diperoleh persen penurunan RH sebesar $12 \%$, dan pada penggunaan zeolit dengan kecepatan $0,178 \mathrm{~m}^{3} / \mathrm{s}$ nilai relative humidity $(\mathrm{RH})$ yang awalnya $83 \%$ menjadi $73 \%$ sehingga diperoleh persen penurunan RH sebesar $10 \%$. Penurunan RH terbanyak diperoleh oleh silika gel dan alumina, meskipun demikian silika gel memiliki daya adsorpsi yang lebih besar dibandingkan dengan alumina dan zeolit [13].

\section{Analisa Permukaan Menggunakan Brenauer Emmett-Teller (BET)}

Salah satu sifat fisik silika gel yang dipengaruhi oleh proses aktivasi adalah luas permukaan spesifik. Pada penelitian ini luas permukaan dianalisis menggunakan metode serapan gas dan dihitung menggunakan metode Brauner-Emmet-Teller (BET) berdasarkan data adsorpsi-desorpsi $\mathrm{N}_{2}$.

Isoterm linier dari sistem adsorpsidesorpsi nitrogen untuk zeolit aktivasi disajikan pada Gambar 9.

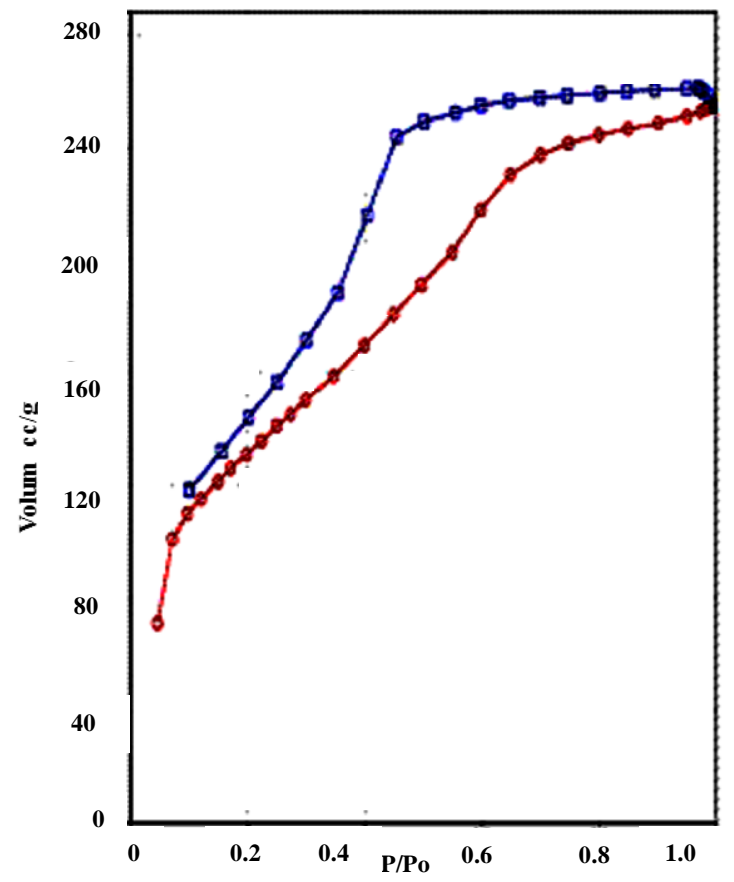

Gambar 9. Isoterm Adsorpsi-Desorpsi Silika Gel

Gambar 9 merupakan grafik jumlah adsorpsi nitrogen (Volum cc/g) terhadap tekanan (relatif $\mathrm{P} / \mathrm{P}_{\mathrm{o}}$ ). Dapat dilihat bahwa isoterm adsorpsi-desorpsi silika gel menunjukkan kenaikan dengan cepat dan terjadi histerisis loop, kemudian naik secara cepat pada $\mathrm{P} / \mathrm{P}_{\mathrm{o}}$ mendekati satu. Ini terjadi karena molekul gas yang teradsorp berinteraksi dengan daerah yang berenergi pada permukaan padatan. Pada pengisian ini telah terbentuk lapisan tunggal (lapisan monolayer). Grafik istoterm ini termasuk grafik tipe IV yang merupakan jenis adsorpsi dari padatan berpori meso (mesopori).

Grafik isotherm dari material mesopori memiliki sifat khas, yaitu terjadinya loop histerisis yang diakibatkan oleh kondensasi kapiler dalam mesopori. Pada tekanan awal, gas yang teradsorp cukup besar karena pori yang masih kosong namun daerah monolayer belum penuh. Seiring dengan peningkatan tekanan mulai terjadi interaksi molekul-molekul gas yang teradsorp pada dinding pori yang saling berhadapan dan keberadaan molekul-molekul tersebut memenuhi mesopori. Sehingga terjadi kenaikan pada kurva isothermal yang disebabkan jumlah gas yang teradsorp sangat besar. Kemudian ketika tekanan diturunkan untuk desorpsi gas, kurva isotherm menunjukkan terjadinya loop histerisis dimana jumlah gas yang terdesorpsi tidak sama dengan jumlah gas yang teradsoprsi di awal. Jumlah gas yang tertinggal di permukaan material ketika desorpsi masih lebih banyak dibandingkan ketika adsorpsi. Hal ini dikarenakan terjadinya kondensasi kapiler pada mesopori [2]. Pada pengujian BET ini juga diperoleh karakteristik silika gel berupa luas permukaan, volume pori, dan diameter masingmasing sebesar $485,174 \mathrm{~m}^{2} / \mathrm{g}, 0,396 \mathrm{cc} / \mathrm{g}$, dan 16,340 Á. Dari hasil BET dapat diketahui bahwa luas permukaan Silika gel tergolong kecil, sehingga pada proses penyerapan silika gel cepat sekali jenuh.

\section{Kesimpulan}

Peningkatan kecepatan udara menyebabkan daya serap desikan terhadap uap air semakin meningkat, dimana daya serap terbaik untuk silika gel diperoleh adalah $0,113 \mathrm{~m}^{3} / \mathrm{s}$ dan $0,178 \mathrm{~m}^{3} / \mathrm{s}$, untuk alumina $0,113 \mathrm{~m}^{3} / \mathrm{s}$ dan 0,178 $\mathrm{m}^{3} / \mathrm{s}$ dan untuk zeolit $0,178 \mathrm{~m}^{3} / \mathrm{s}$. Silika gel pada kecepatan $0,178 \mathrm{~m}^{3} / \mathrm{s}$ mencapai titik jenuh di menit ke-120. Silika gel pada kecepatan 0,113 $\mathrm{m}^{3} / \mathrm{s}$ dan $0,178 \mathrm{~m}^{3} / \mathrm{s}$ memiliki daya serap 0,266 dan 0,264 gram uap air/gram adsorben dengan kelembaban udara akhir 0,0194 dan 0,0198 kg uap air/kg udara kering. Alumina pada kecepatan $0,113 \mathrm{~m}^{3} / \mathrm{s}$ dan $0,178 \mathrm{~m}^{3} / \mathrm{s}$ memiliki daya serap 0,147 dan 0,140 gram uap air/gram adsorben dengan kelembaban udara akhir 0,0207 dan $0,0194 \mathrm{~kg}$ uap air/kg udara kering. Zeolit pada kecepatan $0,178 \mathrm{~m}^{3} / \mathrm{s}$ memiliki daya serap 0,13 gram uap air/gram adsorben dengan kelembaban udara akhir $0,0193 \mathrm{~kg}$ uap air/kg udara kering. Dan hasil karakterisasi Silika gel dengan menggunakan BET diperoleh luas permukaan, 
volume pori, dan diameter pori masing-masing sebesar $485,17 \mathrm{~m}^{2} / \mathrm{g}, 0,39 \mathrm{cc} / \mathrm{g}$, dan $16,34 \AA$ Á.

\section{Daftar Pustaka}

[1] A.M. Husin, Skripsi, Adsorpsi dan Desorpsi Gas Metana pada Bejana Bertekanan (Vessel) dengan Kenaikan Tekanan Secara Bertahap, Fakultas Teknik Program Teknik Mesin Universitas, Depok, 2012.

[2] A.O. Savitri, Skripsi, Sintetis dan Karakterisasi Zeolit ZSM-5 Mesopori Dengan Metode Desilikasi dan Studi Awal Katalisis Oksidasi Metana, Fakultas Matematika dan Ilmu Pengetahuan Alam. Program Studi Kimia Universitas Indonesia, Depok, 2012.

[3] Arnas, Skripsi, Kapasitas Penyerapan $\mathrm{CO}_{2}$ pada Karbon Aktif yang Berasal dari Batubara Sumatera Selatan dengan Tekanan Maksimum 2,3 Bar, Fakultas Teknik. Program Teknik Mesin, Depok, 2008.

[4] A. Sur and R.K. Das, Review on Solar Adsorption Refrigeration Cycle, International Journal of Mechanical Engineering and Technology (IJMET), 101, (2010) 190-226.

[5] Chu, Yu Cheng, L.C. Weng, P.C. Tseng dan C.C. Wang, on Effective Design and Operating Conditions Of Desiccant Dehumidification System, http://tandfonli ne.com, 2017, Diakses pada 19 september 2017

[6] F. Boulevard, Method for Determining Moisture Content by Oven Drying. Department of Transportation, Engineering Service Center, California, 1999

[7] F.T. Ademiluyi and A.A. Ujile, Kinetics of Batch Adsorption of Iron II Ions from Aqueous Solution using Activated Carbon from Nigerian Bamboo, International Journal of Engineering and Technology, 36 (2013) 2049 - 3444

[8] J.D. Seader and E.J. Henley, Separation Process Principles, John Wiley and Sons, USA, 2006, p. 572.

[9] M. Bairuni, Skripsi, Pengaruh Suhu Pengering dan Kecepatan Udara Pada Pengering Kombinasi Konveksi-Desikan, Departemen Teknik Kimia Fakultas Teknik Universitas Sumatera Utara, Medan, 2017.

[10] Nuryono, Peranan Kimia dalam Pengembangan Teknologi Material Berbasis Silika, Makalah yang disajikan pada Pidato Pengukuhan Jabatan Guru
Besar Ilmu Kimia, http://mgb.ugm.ac.id, 2010, Diakses pada 15 Juli 2017.

[11] M. Djaeni, Thesis, Energy Efficient Multistage Zeolite Drying for Heat Sensitive Products, Wageningen University, The Netherlands, 2008.

[12] M. Subota, T. Hanada, S. Yabe and H. Matsuda, Regeneration Characteristics of Desiccant Rotor with Microwave and Hot Air Heating, Energies, 211, (2013) 13353390.

[13] Nazarudin, Zeolit, http://bangnzn.blog .com, 2013, Diakses pada 15 Oktober 2017.

[14] Pandhare, Ghanshyam G, Nikhilesh Trivedi dan S. D. Dawande, Adsorption of Color From A Stock Solution Using Neem Leaves Powder As A Low-Cost Adsorbent. International Journal of Engineering and Technology Vol. 3, No. 6, (2013).

[15] S.N. Chotimah, Sunarto, dan E. Mahajoeno, Producing of Biogas From Food Waste With Substrate Temperature and Variation in Anaerob Biodigester, Jurnal Ekosains, Vol. 3, No. 3, (2011) 2.

[16] Vargas, P. Diana, L. Giraldo and J.C.M. Pirajan, $\mathrm{CO}_{2}$ Adsorption on Activated Carbon Honeycomb-Monoliths A Comparison of Langmuir and Toth Models, International Journal of Molecular Sciences, 214, (2012) 160-171. 